\section{Undernutrition should be the first priority}

Madam,

Public Health Nutrition is now established as an international journal, and you are to be congratulated for that. But as a regular reader I am disappointed and even somewhat dismayed to find so little coverage of undernutrition, as an issue that is at the heart of public health nutrition.

My view, which may be unpopular, is that we who have lived on the fat of the land should face with resignation and dignity the results of our ways of life, which evidently include an increased chance of heart disease and various cancers. We should not selfishly promote the spending of huge sums of money in attempts to prevent or alleviate such diseases that we bring upon ourselves, as well as making immense demands on the services of younger people in the medical, nursing and other professions to look after us. Meanwhile, as everybody knows, hundreds of millions go short.

If the Declaration of Human Rights means anything, it means that children, who were not consulted about being born, have a right to healthy development. I realise that the best policies for achieving this goal are an enormous and controversial subject.

One of the principles of the 'new nutrition science', as published in your pages ${ }^{(1)}$, is as follows: 'The only rational food and nutrition policies are those that take account of global renewable and non-renewable resources'. With this admirable while not entirely new precept in mind, here is just one example of a subject that I believe deserves to be better known and investigated, and whose benefits for undernourished children - and adults - are potentially immense. This is leaf concentrate, at first known as leaf protein.

The development of this product was at first the work of N.W. Pirie, a founding member of the Nutrition Society. He was a Cambridge scientist, elected to the Royal Society for his work on ribonucleic acid in the tobacco mosaic virus. He devoted much of his life thereafter to promoting leaf concentrate as a potentially important contribution to the reduction of undernutrition. A vital part of his work was the design of simple machinery that enabled any community, almost however impoverished, to manufacture their own concentrate from whatever suitable leaves that grew in their fields ${ }^{(2)}$. His work and now that of others gives rise to three questions.

First, should supplementary feeding play any part in a public health strategy? My answer is 'yes', because this can easily be done through mother and child clinics, which are needed for all sorts of other reasons. UNICEF once had a huge programme of distributing dried skimmed milk, but this is an environmentally expensive product.

Second, if the answer to the first question is yes, should leaf concentrate be produced industrially, like the old protein supplements such as Incaparina ${ }^{(3)}$, or should it be produced at the village level? ${ }^{(4)}$ There have been many village-level trials, using very simple machinery, but on the whole they seem not to have been very successful because of problems such as continuity of production. However, there is now available a product made industrially in France from lucerne (alfalfa) which is extremely cheap $^{(4)}$.

Third, does leaf concentrate work? Does it have any value in practice? It was first introduced as a source of protein, but in quite small amounts also supplies significant amounts of vitamin $\mathrm{A}, \mathrm{Fe}$ and other micronutrients. It has been tested in field trials in Central America, Africa and I believe also India, with promising results. I remember seeing the results of one trial in Burundi I think, in children who were HIV-positive, with remarkable results. But such trials are small and done without much statistical back-up, so they don't make the scientific journals.

I offer leaf concentrate as just one example of an initiative that is plausible, simple and sustainable, and which, like undernutrition itself, is neglected. In either case I can think of a number of reasons why this is so, but I cannot think of a good reason.

\section{John Waterlow \\ 15 Hillgate Street, London W8 7SP, UK}

doi: $10.1017 / \$ 1368980008002231$

\section{References}

1. Leitzmann C \& Cannon G (2005) Dimensions, domains and principles of the new nutrition science. Public Health Nutr 8, 787-794.

2. Pirie N (1987) Leaf Protein and Its By-Products in Human and Animal Nutrition, 2nd revised ed. Cambridge: Cambridge University Press.

3. Hussey J (1969) Pitfalls between production and consumption of new protein foods: Incaparina in Columbia. J Dairy Sci 52, 422-424.

4. Kennedy D \& Leaf for Life (1993) Leaf Concentrate: A Field Guide for Small Scale Programs. http://www.leafforlife. org/PDFS/english/Leafconm.pdf (accessed March 2008).

\section{Editor's note}

Professor Waterlow's letter coincides with our coverage $^{(1-3)}$ this month of the Lancet undernutrition series, published earlier this year, and its implications. He is right, and we will aim to do better, both in our editorial pages and in the original papers we select.

\section{References}

1. Margetts B (2008) What we should be saying - and doing about undernutrition. Public Health Nutr 11, 547-548.

2. Cannon G (2008) Out of the Box. Public Health Nutr 11, 550-553.

3. Uauy R (2008) Undernutrition is undernourished. Public Health Nutr 11, 647-649. 